\title{
Landfill Site Selection: a Basis Toward Achieving Sustainable Waste Management
}

\author{
Azadeh Jamshidi ${ }^{1 *}$, Elmira Kazemi Jahandizi', Minoo Moshtaghie², \\ Seyed Masoud Monavari ${ }^{3}$, Sanaz Tajziehchi ${ }^{3}$, Alireza Hashemi ${ }^{4}$, \\ Mojgan Jamshidi', Leili Allahgholi ${ }^{1}$

\begin{abstract}
'Department of Environment and Energy, Science and Research Branch, Islamic Azad University, Tehran, Iran
${ }^{2}$ Young Researchers and Elite Club, Khorasgan (Isfahan) Branch, Islamic Azad University, Isfahan, Iran

${ }^{3}$ Department of Environment, Faculty Environment and Energy, Science and Research Branch,

Islamic Azad University, Iran

${ }^{4} \mathrm{Head}$ of Tarlan Ornithological Group
\end{abstract}

Received: 7 June 2014

Accepted: 3 August 2014

\begin{abstract}
The improper collection and disposal of waste can cause serious problems in the near future. Unfortunately, in developing countries this issue has not been adequately addressed. The upward trend of waste production, on one hand, and lack of strategies to manage such materials, on the other hand, have been seen in many areas - especially metropolitan cities with serious problems - have led to a lot of environmental damage. Moreover, there are also some waste disposal drawbacks in cities. This study is a GIS approach aimed to perform a systematic landfill site selection study by introducing a decision support system for sustainable household waste management using a value-focused multi-criteria method. For this purpose, Sarab County was selected as a case study. The research shows how effective the multi-criteria method is in handling wide ranges of criteria involved in site selection studies.
\end{abstract}

Keywords: value-focused approach, GIS, landfill, site selection

\section{Introduction}

Population growth, urbanization, the emergence of new technologies, and changes in lifestyle and consumption patterns on the one hand, and restrictions on the use of natural resources have, on the other hand, led social, economic, and even environmental conflicts in addition to creating a variety of complex problems regarding the quality of human life [1]. Production and disposal of wastes, in different levels of quality and quantity, are considered to be among the major issues challenging human communities. In most cities of Iran, waste dumping is the most common

*e-mail: azadeh_jamshidi@ymail.com method for waste disposal. Only factors such as transportation distance and costs are accounted for in waste dumping and site selection, whereas economic aspects cannot be solely responsive to the resulting health and environmental requirements.

Since the city is a living and dynamic system, proper site selection and spatial distribution of land use and the relationships between them are the major issues that must be considered. On the other hand, because any land use has particular characteristics and requirements, appropriate site selection must be conducted to avoid conflicts between land uses [2]. Nowadays, controlling and reducing the impacts of municipal waste in order to protect the environment is considered one of the major issues and concerns in 
urban communities [3]. With the Waste Management Act in Iran (from about five years ago), the responsibility for the management and elimination of municipal waste has become more transparent, and municipalities bear more burden. According to the Waste Act of the Islamic Republic of Iran approved in 2005 (1384 Solar), "waste" refers to the solid, liquid, and gaseous material (other than sewage) that result directly or indirectly from human activity, and are considered superfluous from the producer point of view.

According to the United Nations (UN) and Iran Department of the Environment (DoE), in developed countries approximately $80 \%$ of waste is recycled and reused, and the rest are sent to the sanitary landfill or incinerator facilities. While in Iran only about 8\% of waste is recycled, and the rest is mainly land filled in an unsanitary manner [4]. Therefore, the basic efforts should be put forward in this area, especially in municipal waste management, to minimize resulting losses.

Increasingly urban population growth in the world, and in different countries (especially in recent years) has caused excessive consumption resulting in the increased generation of household waste in urban areas. Lack of attention to environmental concerns, as a risk, in many cities of Iran, threatens the landfill environment, but what has made waste collection and landfilling necessary and inevitable is the observance of health issues. Much of municipal waste has characteristics that endanger human and other organisms' health in natural environments and cause problems in human environments [5-8]. Air, soil, surface, and groundwater pollution and its contribution to create a favorable environment for insects and vermin are the main problems caused by unsanitary waste disposal, which can expose citizens to risk and fatal disease, and may even cause mass mortality in a community [9-12].

So one of the major challenges facing urban managers today is properly landfilling waste. In recent years, problems resulting from population growth and, consequently, the non-engineered landfilling of household waste, have threatened health and the environment in Sarab City. Therefore, as mentioned above, site selection for household waste landfilled with the purpose of fighting health and environmental problems in order to have a healthy city is essential.

Lack of attention to proper siting of a household waste landfill in Sarab City will impose irreversible impact and damage to various resources, especially on the water and soil resources of the studied area. It is clear that open dumping of such material on the ground causes greenhouse and toxic gas emissions that are inconsistent with the Kyoto Protocol. In addition, rainwater infiltration through waste or sometimes groundwater penetration into the waste can also generate toxic leachate, contributing to pollution dispersion and development in the area. So this study tries to provide a comprehensive framework based on sustainable principles in the sanitary landfill site selection for the household waste by providing a decisionmaking support system.

\section{Materials and Methods}

\author{
Materials
}

1. Spot satellite data (2005)

2. 1:25000-scale topographic maps of Sarab City (Armed Forces Geographical Organization)

3. 1:100000-scale geologic maps (Department of Geological Survey and Mineral Exploration)

4. Groundwater map and landfill distance from wells maps (Azarbaijan-e-sharghi Water and Wastewater Organization)

In addition to these base maps, slope classification, slope direction and altitude, faults, distance from main roads, transmission lines, and surface water maps were provided using existing topographic maps. A land use map was also provided using spot satellite imagery.

\section{Software}

1. Autodesk Map 2004 Software was applied for digitizing and map editing.

2. Expert choice software was used for weighing the criteria using AHP method and spatial multi-criteria evaluation.

3. ArcGIS Software was used for creating and completing a database layer, georeferencing maps, specifying the coordinate and image systems, using the spatial analysis functions for performing the multi-criteria evaluation, and - regarding the high editing and questionanalysis capabilities of the software - information layers were developed, summarized, and questioned.

\section{Analysis}

Considering that the aim of this study is to select the best possible site for solid waste landfill and therefore needs to evaluate a set of alternatives based on different criteria, to achieve this purpose and to set the priorities in compliance with criteria by decision makers we used MADM with multi-objective decision making. Parameters were weighted using binary comparison and the procedures described in this chapter; but before addressing the process, we needed to obtain information about the predicted site regarding population growth of Sarab City and annual waste generation.

\section{Landfill Site Area}

In order to calculate the area required for landfill, factors such as waste generation rate, population. and density of the compressed landfill material should be considered. Therefore, population growth and annual waste generation, and the shape and height of the landfill site need to be addressed as well.

After extracting various information layers, the maps were transformed into the layers applicable to the GIS environment; then we performed site selection in appropriate software. 
The purpose of multi-criteria decision-making evaluation is to select the best or most preferred alternative, to regulate the alternatives that seem proper, and to sort alternatives in descending order of preference.

\section{Weighting Method}

Once the evaluation criteria were converted into the comparable and standard scales, weight and relative importance of each criterion were determined in relation to intended purpose. In this paper we used the Nixon et al. analytic hierarchy process (AHP) to assign a relative weight to each particular criterion [13]. It is a powerful and flexible tool for the qualitative and quantitative study of multi-criteria problems characterized by binary comparison of layers [14]. The procedure consists of three main stages:

1. Defining and organizing the criteria in a hierarchy (developing the matrix of criteria). In this study, a set of binary comparisons between relative importance values of the criteria is done for intended evaluation.

2. Then they are analyzed to develop a series of weights (the sum of those is equal to 1). Criteria and the relative weights are considered the main input data of multi-criteria evaluation in GIS.

3. The consistency index (CI) is calculated based on the latent vector of graph theory to determine the accuracy of weighting $[13,15]$. If the value of the consistency index is less than or equal to 0.1 , the weighting is considered accurate; otherwise, the relative weights assigned to the criteria should be altered and re-weighting must be conducted.

\section{Landfill Site Area}

In order to calculate the area required for landfill, factors such as waste generation rate, population, and density of the compressed landfill material should be considered. Therefore, the population growth and annual waste generation and the shape and height of the landfill site need to be addressed, as well.

\section{Population Growth Rate}

Since the waste generation rate increases in parallel with the population growth rate, we consider the population growth rate to be the same as the waste generation rate. Considering that the Sarab City populations in 1997 and 2007 were 14,883 and 133,617 , respectively, we can use the following equation to calculate the population growth rate (Statistical Center of Iran, 1997 and 2007):

$$
P_{97}=P_{07}(1+r)^{10}
$$

...where: $P_{97}$ is the population in 1997, $P_{07}$ is the population in 2007 , and $\mathrm{r}$ is the population growth rate equal to $0 / 011 \%$.

\section{Volume of Waste Generated Annually}

Considering that waste generation per day is 45 tons in Sarab City, we can calculate the annual volume of waste generation as follows (waste density is $500 \mathrm{~kg}$ ):
Annual waste generation $(Q)$ (tons per year) $=$ 365 (tons per day) waste generation rate

Annual waste volume $(V)\left(\mathrm{m}^{3}\right.$ per year $)=$ tons per year/density

Annual waste generation $=16,425$

Annual waste volume $=32.85$

Since the waste generation growth rate is considered equal to population growth, considering the 20 -year landfill design period, the volume of waste produced in a 20 -year period is calculated as follows:

$$
\begin{gathered}
\text { weight }_{20}=\text { q.tons } / \text { year } \times \frac{(1 \times r)^{20}-1}{r} \\
v_{20}=\frac{\text { weight }_{20}}{0 / 5}
\end{gathered}
$$

Tons for 20 years $=592,670.246$

Volume of waste generated in a 20 -year period $\left(\mathrm{M}^{3}\right)=711,204.259$

\section{Height and Shape of Landfill}

If a three-dimensional figure consisting of two frustums sticking together (reversely) by their rectangular basis is considered for landfill with the side $S$ at ground level, a height $H_{g}$ underground, and a height $H_{U}$ above ground level $\left(H_{g}=H_{U} / 2, H_{U}=H_{a}+H_{g}\right)$, given the required capacity for a 20 -year period, the length of $S$ as well as the required area for the landfill at ground level $S^{2}$ could be calculated [16].

$$
V=1.5 H_{U}\left[S^{2}+8.11 H_{U}\left(H_{u}-0.535 \mathrm{~S}\right)\right]
$$

Now, according to the above equation, and because $20 \%$ of the total capacity of the landfill site should be allocated to soil cover, then we have:

$$
V=V_{20} \times \frac{1}{2}
$$

...where $V$ shows volume required for solid waste landfill.

If we assume that the landfill height averages $10 \mathrm{~m}$, the length of the side at ground level $(S)$ could be calculated as follows, and then, by placing the length of the side at ground level $(S)$ into the above equation, we can calculate the land area required for landfill $\left(S^{2}\right)$ in a 20-year horizon:

$$
\begin{gathered}
S^{2}=\frac{V}{H} \\
H_{U}=10 \\
S^{2}=7.112 H_{a}
\end{gathered}
$$

The resulting value is the minimum area, which usually varies from $20-40 \%$ (30\% on average), taking into account the transportation routes, buildings, equipment, services, and so on, so that we have:

$$
S^{2}=7.112(1+0.3)=10\left(H_{a}\right)
$$




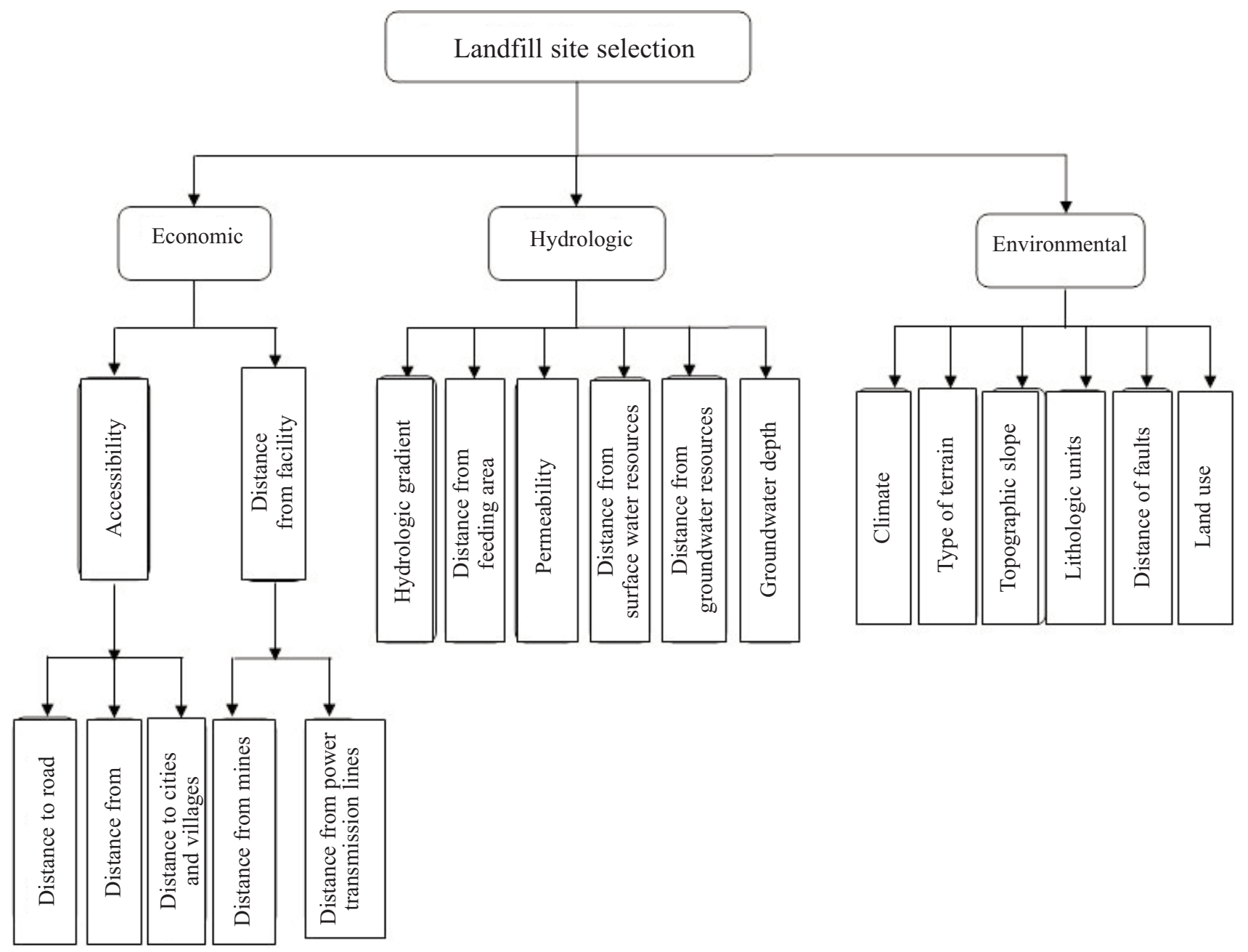

Fig. 1. Decision tree for landfill site selection.

\section{Study Area}

Sarab City is located between $37^{\circ} 45^{\prime} 28^{\prime \prime}$ and $38^{\circ} 15^{\prime}$ $28^{\prime \prime} \mathrm{N}$, and $46^{\circ} 59^{\prime} 14^{\prime \prime}$ and $47^{\circ} 56^{\prime} 32^{\prime \prime} \mathrm{E}$, in west central Azarbaijan-e-Sharghi province (Fig. 1). The city consists of two districts, 9 rural districts, 4 towns, and 168 villages with residents.

\section{Methodology}

We used the spatial multi-criteria evaluation (SMCE) and developed the decision support system (DSS) for Sarab household waste landfill site selection and evaluation. SMCE provide an appropriate solution for evaluating the information layers, and subsequently for identifying the proper site for a household waste landfill (Siddiqui, 1196). The following steps were passed in the study to determine the DSS:

\section{Determining the Criteria and Drawing the Hierarchical Structure:}

In order to identify the proper sites for disposal and land filling the household waste within Sarab City limits, we did preliminary studies and recognized the criteria influencing the selection of the household waste landfill site. Then the intended criteria were extracted from confirmed and attributable domestic and foreign references such as EPA, British Colombia, Iran Department of the Environment, Iran Management and Planning Organization, and some of the consulting engineering institutes.

Accordingly, determined criteria include:

1. Main hydrological-hydro geological criteria, including distance from surface water resources (rivers, lakes, and so on) and distance from groundwater resources (well, spring, subterranean), plus groundwater depth, soil permeability, hydraulic slope, and aquifer feeding areas

2. Main environmental criteria, including: land use, geomorphology, topographic slope, litho logical units, distance from existing faults in the study area, average rainfall, type of climate

3. Main socio-economic issues criteria, including: distance from infrastructures, accessibility

After identifying the major criteria involved in the process of landfill site selection, these criteria were sorted into a decision tree (Fig. 1). 
Table 1. Judgment scale for pair-wise comparisons [17].

\begin{tabular}{|c|l|}
\hline Scale & \multicolumn{1}{|c|}{ Descriptions } \\
\hline 1 & Equally preferred \\
\hline 2 & Equally to moderately \\
\hline 3 & Moderately preferred \\
\hline 4 & Moderately to strongly \\
\hline 5 & Strongly preferred \\
\hline 6 & Strongly to very Strongly \\
\hline 7 & Very Strongly preferred \\
\hline 8 & Very Strongly to extremely \\
\hline 9 & Extremely preferred \\
\hline
\end{tabular}

\section{Dimensionless (to Incommensurate) the Criteria Maps}

The prepared maps should be standardized. Values have different meanings in different maps and they have been expressed in different units (for example, slope map in terms of percentage, temperature in degrees, etc.). So it is necessary to standardize all values to become comparable. In other words, the values are converted into common units (from 0 to 1 ), a process called dimensionless. In this study, we have served the cost-benefit analysis to incommensurate the distance criteria, and the pair comparison method is also used to incommensurate other criteria.

$$
n_{i, j}=\frac{r_{i, j}}{\sum_{i=1}^{n} r_{i}, j}
$$

\section{Criteria Weighting}

Following the criteria selection, the effectiveness of each criterion will be determined to indicate suitability, unsuitability, and/or degree of suitability to the site features. In this case, the membership of each criterion should be specified depending on the considered criteria and parameter type. That is, the range between the worst and the best conditions for the rating (scoring) should be determined. For weighting the criteria, we used the paired comparison technique of AHP [17], in which the criteria were compared together as paired or binary, determining the weight of each criterion compared to others (Table 1).

Where, if the value of the inconsistency rate is less than 0.1 , the weighting is considered to be acceptable; otherwise, the comparisons should be reviewed. The following steps are used for calculating the inconsistency rate:

1. Calculating the weighted sum vector: Multiply the paired comparisons matrix by the column vector "relative weight"; call the resulting new vector the "weighted sum vector."

2. Calculating the consistency vector: Divide the weighted sum vector components by relative priority vector. The resulting vector is called "consistency vector."

3. Deriving $\lambda_{\max }$ : Average of consistency index components give the $\lambda_{\max }$.

4. Calculating the consistency index, defined as follows:

$$
C I=\frac{\lambda_{\max }-n}{n-1}
$$

...where $n$ is the number of alternatives in the question.

5. Calculating the consistency ratio, derived by dividing the consistency index by the random index.

$$
C R=\frac{C I}{C R}
$$

A consistency ratio less than or equal to 0.1 indicates consistency in comparisons.

The random index is obtained from Table 2.

\section{Overlaying the Criteria Maps Using Suitability Index (SI)}

In this stage we integrated the weighted information layers using GIS, and identified the appropriate areas for waste landfill site. Then results were adapted to field information and data. Finally, some recommendations are provided for proper site selection.

The suitability index was calculated for ranking the spatial objects.

$$
\begin{gathered}
S I=R I . A 1 * \sum_{i=1}^{m} R I . B i * R I . K B i+ \\
R I . A 2 * \sum_{y=1}^{L} R I C y * R I K C y+\ldots \\
R I A N * \sum_{z=1}^{j} R I D z * R I K D z
\end{gathered}
$$

...where $S I$ is the suitability index of each cell; $N$ is the number of main criteria; RIA1, RIA2 .. RIAN are the relative importance of the main criteria $A 1, A 2 \ldots A \mathrm{~N}$, respectively; $M, L$, and $J$ are the number of sub criteria directly connected to the main criteria $A 1, A 2 \ldots A N$, respectively; $R I B$, $R I C$, and RID are the relative importance of sub criteria $B$,

Table 2. Random index.

\begin{tabular}{|c|c|c|c|c|c|c|c|c|c|c|c|c|c|c|c|}
\hline $\mathrm{N}$ & 1 & 2 & 3 & 4 & 5 & 6 & 7 & 8 & 9 & 10 & 11 & 12 & 13 & 14 & 15 \\
\hline R.I. & 0 & 0 & 0.58 & 0.90 & 1.12 & 1.24 & 1.32 & 1.41 & 1.45 & 1.49 & 1.51 & 1.48 & 1.56 & 1.57 & 1.58 \\
\hline
\end{tabular}


Table 3. Scenario 1 in the process of siting the municipal waste landfill.

\begin{tabular}{|c|c|c|}
\hline \multirow{2}{*}{$\begin{array}{c}\text { Suitable site for } \\
\text { household landfill }\end{array}$} & Economic issues & $194 / 0$ \\
\cline { 2 - 3 } & Hydrological issues & $611 / 0$ \\
\cline { 2 - 3 } & Environmental issues & $194 / 0$ \\
\hline
\end{tabular}

Table 4. Scenario 2 in the process of siting the municipal waste landfill.

\begin{tabular}{|c|c|c|}
\hline \multirow{2}{*}{$\begin{array}{c}\text { Suitable site for } \\
\text { household landfill }\end{array}$} & Economic issues & 0.194 \\
\cline { 2 - 3 } & Hydrological issues & 0.194 \\
\cline { 2 - 3 } & Environmental issues & 0.611 \\
\hline
\end{tabular}

$C$, and $D$ directly connected to the main criteria $A 1, A 2 \ldots$ $A \mathrm{~N}$, respectively; $R I K B, R I K C$, and $R I K D$ are the relative importance of indicators category $k$ of sub criteria $B, C$, and $D$, and main criteria $A 1, A 2 \ldots A N$, respectively. This equation is prepared to four levels of hierarchy and hence needs to be modified for a decision hierarchy with more or fewer levels [18-21].

\section{Results and Discussion}

The results of the study are presented in the following 4 management scenarios:

- Scenario 1 focuses on hydrological criteria, followed by environmental and economic criteria, which receive minimum weight, equally. Following the integration of

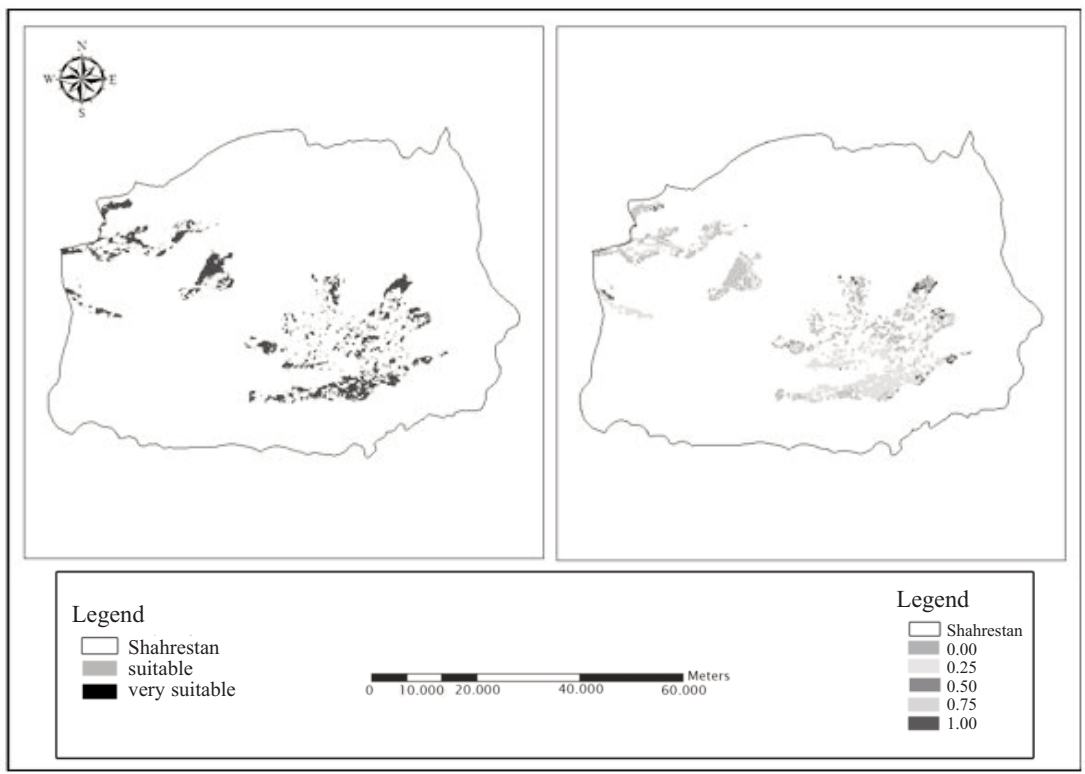

Fig. 2. The proper municipal waste landfill sites in scenario 1 .

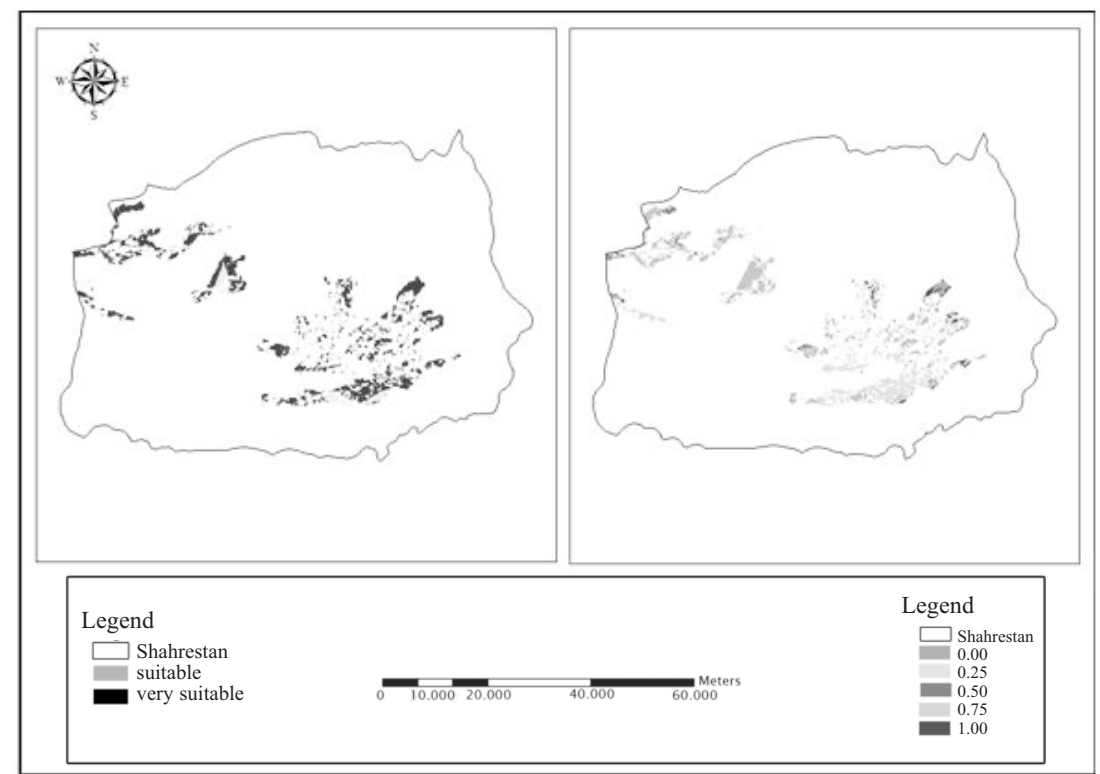

Fig. 3. The proper municipal waste landfill sites in scenario 2 . 
Table 5. Scenario 3 in the process of siting the municipal waste landfill.

\begin{tabular}{|c|c|c|}
\hline \multirow{2}{*}{$\begin{array}{c}\text { Suitable site for } \\
\text { household landfill }\end{array}$} & Economic issues & 0.611 \\
\cline { 2 - 3 } & Hydrological issues & 0.194 \\
\cline { 2 - 3 } & Environmental issues & 0.194 \\
\hline
\end{tabular}

Table 6. Scenario 4 in the process of siting the municipal waste landfill.

\begin{tabular}{|c|c|c|}
\hline \multirow{2}{*}{$\begin{array}{c}\text { Suitable site for } \\
\text { household landfill }\end{array}$} & Economic issues & 0.33 \\
\cline { 2 - 3 } & Hydrological issues & 0.33 \\
\cline { 2 - 3 } & Environmental issues & 0.33 \\
\hline
\end{tabular}

the information layers in this scenario, the appropriate range for municipal landfill was determined. The rightside picture is output of ILWIS, which was reclassified, followed by the left-side picture (Table 3, Fig. 2).

- Scenario 2 places more importance on environmental criteria followed by hydrological criteria. Economic criteria have the lowest weight. After integrating the information layers in this scenario, the proper range for municipal waste landfill was identified. The right picture is output of the ILWIS, which was reclassified and turned to the left picture (Table 4, Fig. 3).

- Scenario 3 gives more importance to economic criteria, followed by environmental and hydrological criteria having equal weights. The right picture is output of the ILWIS, which is transformed into the left picture after reclassifying (Table 5, Fig. 4).

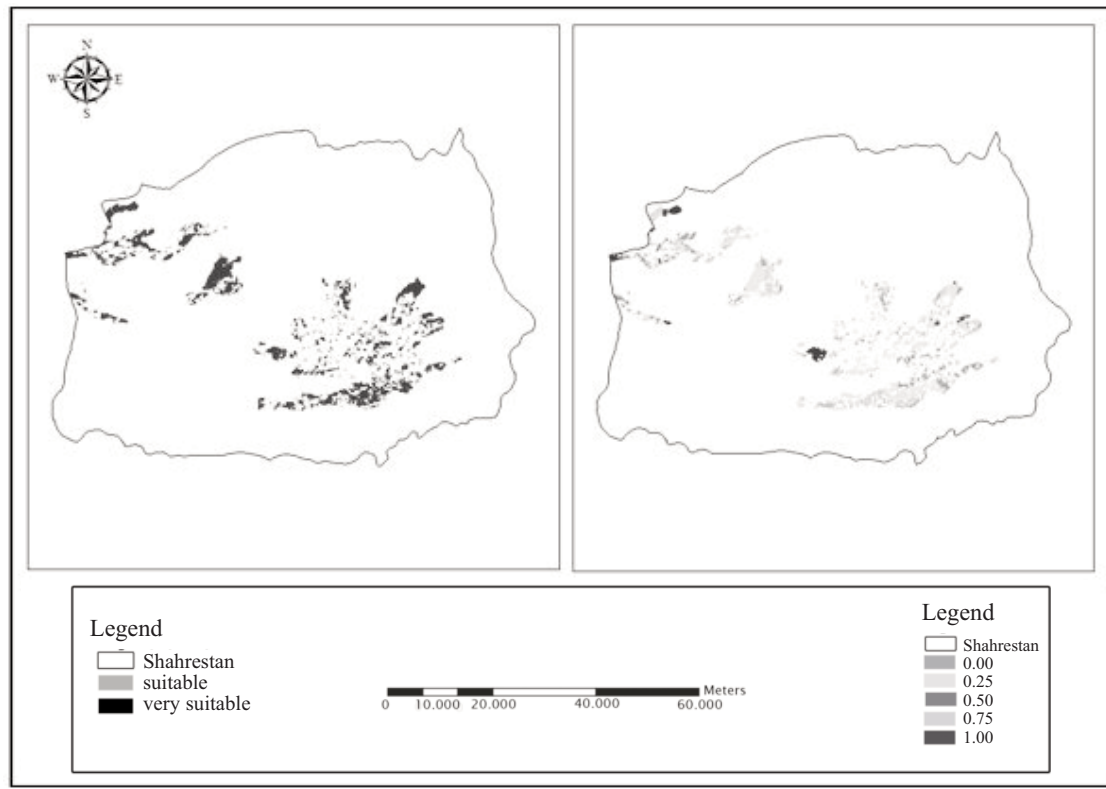

Fig. 4. The proper municipal waste landfill sites in scenario 3.

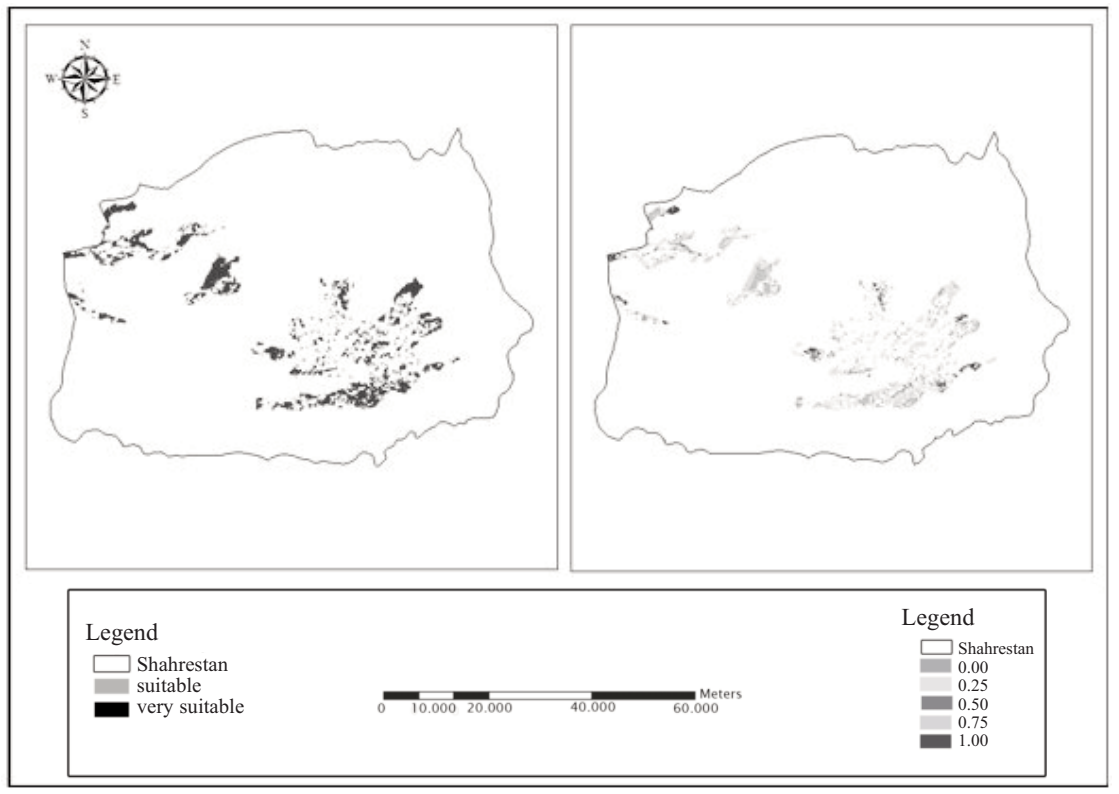

Fig. 5. The proper municipal waste landfill sites in scenario 4 . 
All the main objectives have same weight in scenario 4. It is assumed that all determining criteria in siting the municipal waste landfill have the same importance in landfill site selection. The right picture is output of the ILWIS, which is transformed into the left picture after reclassifying (Table 6, Fig. 5).

In the above figures, areas with high suitability for sanitary landfill are shown in light grey and areas with very low suitability are shown in dark grey.

\section{Conclusion}

The landfill site selection process in Iran has so far been based mainly on field surveys and old aerial photographs. Therefore, many criteria have been neglected, and from the technical point of view this process was time-intensive and the results had unacceptable accuracy, as well. Using more criteria to influence the objective, spending less time, improving result accuracy, using expert comments individually or as a group, and producing, applying, and extracting digital data are all advantages from using MCDM and GIS in the form of SDSS. Results indicate that MCDM together with GIS could be applied as a powerful and efficient tool for siting a special waste landfill.

Geological conditions, geomorphology, pedology, and also desirable climate conditions, being outside the domain of surface and groundwater resources, having proper distance from population centers, economic justifiability of selected sites, and controlling and adapting these sites by means of field surveys and satellite images all confirm the effectiveness of SDSS.

This paper indicates that if using MCDM, complicated and difficult issues such as siting the special waste landfill could be simplified by dividing them into affective components and criteria.

In addition, by applying MCDM, the qualitative influential criteria involved in landfill site selection are integrated into numerical and computable data, and decision-making based on the mathematical calculations would be possible.

In general, what might be concludes from this study is that GIS with the ability to apply various functions and the possibility of changing and manipulating data and the ability to integrate the different information layers quickly, as well as the possibility of using satellite images and results from interpreting these images, create a unique tool for site selection. And performing site selection studies in a vast scale with proper accuracy and speed without GIS might be difficult and time intensive.

One of the results from applying GIS is that we may ignore areas inappropriate for landfill, performing more detailed and affordable studies on the rest area. Thus, GIS with its diverse abilities leads us to cost reduction and fast achievement of our intended goal.

\section{Acknowledgements}

The authors greatly appreciate editing services offered by Ravian Danesh Mohit Company.

\section{References}

1. MONAZZAM M.R., GOLMOHAMMADI R., NOUROLLAHI M., FARD S.M.B. Assessment and control design for steam vent noise in an oil refinery. Journal of Research in Health Sciences, 1, (1), 14, 2011.

2. ABBASPOUR M., KARIMI E., NASSIRI P., MONAZZAM M.R., TAGHAVI L. Hierarchal assessment of noise pollution in urban areas - A case study. Transport. Res. D-Tr. E., 34, 95, 2015.

3. SLAGSTAD H., BRATTEBØ H. Influence of assumptions about household waste composition in waste management LCAs. Waste Manage. 33, (1), 212, 2013.

4. TAGHIZADEH F. Evaluation and site selection of petrochemical industrial waste land filling using SMCE method. J. Food, Agric. Environ. 9, (1), 684, 2011.

5. MOY P., KRISHNAN N., ULLOA P., COHEN S., BRANDT-RAUF P. W. Options for management of municipal solid waste in New York City: A preliminary comparison of health risks and policy implications. J. Environ. Manage. 87, (1), 73, 2008.

6. AYOMOH M. K. O., OKE S. A., ADEDEJI W. O., CHARLES-OWABA O. E. An approach to tackling the environmental and health impacts of municipal solid waste disposal in developing countries. J. Environ. Manage. 88, (1), 108, 2008.

7. KUMAR AWASTHI M., PANDEY A., KHAN J., BUNDELA P. S., WONG J. W., SELVAM A. Evaluation of thermophilic fungal consortium for organic Municipal solid waste composting. Bioresource Technol. 2014. doi: 10.1016/j.biortech.2014.01.0484.

8. NADAL M., INZA I., SCHUHMACHER M., FIGUERAS M. J., DOMINGO J. L. Health risks of the occupational exposure to microbiological and chemical pollutants in a municipal waste organic fraction treatment plant. Int. J. Hyg. Envir. Heal. 212, (6), 661, 2009.

9. CANGIALOSI F., INTINI G., LIBERTI L., NOTARNICOLA M., STELLACCI P. Health risk assessment of air emissions from a municipal solid waste incineration plant - A case study. Waste Manage. 28, (5), 885, 2008.

10. KIM Y. M., KIM J. W., LEE H. J. Burden of disease attributable to air pollutants from municipal solid waste incinerators in Seoul, Korea: A source-specific approach for environmental burden of disease. Sci. Total Environ. 409, (11), 2019, 2011.

11. RANJAN RAY M., ROYCHOUDHURY S., MUKHERJEE G., ROY S., LAHIRI T. Respiratory and general health impairments of workers employed in a municipal solid waste disposal at an open landfill site in Delhi. Int. J. Hyg. Envir. Heal. 208, (4), 255, 2005.

12. MUSTAFA S. S., MUSTAFA S. S., MUTLAG A. H. Kirkuk municipal waste to electrical energy. Int. J. Elec. Power. 44, (1), 506, 2013.

13. BARKER T. J., ZABINSKY Z. B. A multicriteria decision making model for reverse logistics using analytical hierarchy process. Omega. 39, (5), 558, 2011.

14. VERONESE BENTES A., CARNEIRO J., FERREIRA DA SILVA J., KIMURA H. Multidimensional assessment of organizational performance: Integrating BSC and AHP. J. Bus. Res. 65, (12), 1790, 2012.

15. GBANIE S. P., TENGBE P. B., MOMOH J. S., MEDO J., KABBA V. T. S. Modelling landfill location using Geographic Information System (GIS) and Multi-Criteria Decision Analysis (MCDA): Case study Bo, Southern Sierra Leone. Appl. Geogr. 36, 3, 2013. 
16. JAMSHIDI A. Municipal landfill site selection using Multicriteria Decision Making - a case study of Sarab County. M.Sc. thesis, Department of Environment and Energy, Science and Research Branch, Islamic Azad University, Tehran, Iran, 2010.

17. DURBACH I., LAHDELMA R., SALMINEN P. The analytic hierarchy process. Eur. J. Oper. Res., 238, (2), 552, 2014.

18. KHEIRKHAH ZARKESH M. Decision support system for floodwater spreading site selection in Iran.Ph.D. Thesis, ITC, International Institute for Geo-information Science and Earth observation, Enschede, The Netherlands, 2005.
19. ZAREDAR N., KHEIKHAH ZARKESH M. M., GHADIRPOUR A., JOZI S. A., JAFARI S. Investigation of fuzzy as well as Boolean logics application in land evaluation. (Case study: Taleghan basin-Iran). International Conference on Chemistry and Chemical Engineering (ICCCE), Kyoto, Japan, 1-3 Aug. 2010.

20. CAO L., CHENG Y., ZHANG J., ZHOU X., LIAN C. Application of Grey Situation Decision-Making Theory in Site Selection of a Waste Sanitary Landfill. J. China Univ. Mining Technol. 16, (4), 393, 2006.

21. JAFARI S., ZAREDAR N. Land Suitability Analysis using Multi Attribute Decision Making Approach. Int. J. Environ. Sci. Dev. 1, (5), 441, 2011. 
